Mergers and Target Transparency

\author{
Iftekhar Hasan \\ Fordham University \\ Jarl G. Kallberg \\ Washington State University Carson College of Business \\ Crocker H. Liu \\ Cornell University School of Hotel Administration \\ Xian Sun \\ Johns Hopkins Carey Business School
}

Chapter prepared for Corporate Governance in the US and Global Settings (Advances in Financial Economics, Volume 17) Edited by: John, K., Makhija, A. K., \& Ferris, S. P. 


\begin{abstract}
We empirically investigate the hypothesis that the less transparent (more difficult to value) the target's assets are the more likely it is that the acquiring firm can obtain higher short- and longterm returns. We analyze a sample of 1,538 friendly acquisitions partitioned in two separate dimensions: acquisitions of public versus private firms, and acquisitions of a firm’s assets versus acquisitions of a firm's assets and its management. Using a sample of (nondiversifying) real estate transactions with a public REIT as the acquirer, we find that acquisitions of public firms have insignificant short-term abnormal returns. Acquisitions of private targets have positive and significant short-term abnormal returns. The acquirer's abnormal returns are higher in both cases when the transactions involve acquisition of the target firm's management. We find parallel results when analyzing the acquirer's $Q$ over the merger year and the three following years. Our conclusions are robust to the type of financing (cash, stock, or a combination) used in the acquisition.
\end{abstract}

Keywords: mergers and acquisitions; information asymmetry; value of firms 


\section{Mergers and Target Transparency}

In spite of the extensive theoretical and empirical research on mergers, no clear consensus has emerged with respect to its motivations or its impact on the acquirer's shareholders. This lack of agreement is surprising, since few areas of corporate finance are as important or have been subject to more analysis.

Decades of evidence on M\&As demonstrates that acquirers experience losses on average, especially when taking over public targets (Moeller, Schlingemann, \& Stulz, 2004). Transactions involving taking over private targets, however, are found to offer acquirers' shareholders positive and significant announcement abnormal returns (Aktas, de Bodt, \& Roll, 2013; Chang, 1998; Faccio, McConnel, \& Stolin, 2006; Francis, Hasan, Sun, \& Waisman, 2014; Fuller, Netter, \& Stegemoller, 2002; Hansen \& Lott, 1996; Officer, 2007; Officer, Poulsen, \& Stegemoller, 2009). These studies also proposed various hypotheses to understand this phenomenon, none seems be conclusive.

The difficulty of explaining such variation is that announcement returns usually reveal information about various things, some of which are deal-specific and the other may be related to the reevaluation of acquirers (Grinblatt \& Titman, 2002, p. 708). Hietala, Kaplan, and Robinson (2001) argue it is often impossible to isolate various effects and know the reason for the market's reactions to an announcement.

By examining acquirers with several M\&A deals, Fuller et al. (2002) are able to more directly examine the impact of target and deal-specific characteristics. They proposed that the liquidity discount, tax, and control effects may explain the positive returns of acquiring private targets. Their findings suggest that private firms and subsidiaries are less attractive investment and thus less valuable than similar more liquid public firms. Private targets, however, could be 
good investment because they offer additional benefits to already diversified shareholders through helping internalize externalities (Hansen \& Lott, 1996). Hansen and Lott (1996) argue that if shareholders are diversified and own both shares of acquirers and targets, they do not care whether acquirers overpay for shares of listed companies but would demand that managers not overpay for unlisted targets.

The main purpose of this study is to analyze the short- and long-term performance of firms acquiring targets with different degrees of transparency (difficulty in valuation). The possibility of achieving success in a merger depends in large part on the acquirer's ability to identify attractive targets. Targets are attractive either because they are undervalued by other potential acquirers, or because they might have greater synergies with a specific acquirer. In addition, information costs and valuation uncertainty vary by target type and are generally higher for acquiring private targets or for acquiring intangible rather than physical assets.

We hypothesize that acquiring assets that are less transparent (more difficult to value) will lead to higher returns in the long and short run than acquiring assets that are relatively easy to value. That is, we assume that the possibility of the acquirer having an informational advantage over other potential acquirers will be higher when, for example, the asset is private or its assets are less tangible. This informational advantage is reflected in that such hypothesis will hold regardless of the payment method. Several studies show that taking over private targets with stock yield particularly higher returns because: (i) the risk sharing hypothesis (Fuller et al., 2002 among others) (ii) the block shareholder hypothesis (Chang, 1998). To distinguish our hypothesis from theirs, we argue that acquirers having informational advantage enjoy higher returns regardless of the payment method. 
Specifically, we analyze acquisitions in two separate dimensions: acquisitions of public versus private firms, and acquisitions of a firm's assets versus acquisitions of a firm’s assets and its management. Our hypothesis implies that it should be very difficult to achieve abnormal returns or to have a viable informational advantage when the target is publicly traded. Conversely, acquiring private firms should offer the acquirer more scope to exploit an informational advantage. This potential should be even greater if the target's assets are more difficult to value, which would be the case if the acquisition involved the retention of the target's management. We use the retention of management because it allows us to partition our sample by differing degrees of transparency. Our focus is not on the retention of management per se. Thus, our hypothesis suggests the following partial ordering of our four categories of transactions: the lowest returns should result from acquisitions of a public firm's physical assets only; the highest returns should come from acquiring the management and assets of a private company. Returns to acquiring both the management and assets of a public firm, or to acquiring the physical assets of a private firm, will fall between these two extremes.

We test our hypothesis by examining 1,538 acquisitions from January 1990 to December 2000. Our time frame ends in 2000 to allow us to compute long-term abnormal returns and operating performance. We focus on real estate transactions to avoid industry-specific effects and because real estate is an industry in which each of the four types of acquisitions analyzed is prevalent. We further specialize our empirical analysis to acquirers that are equity real estate investment trusts (REITs), since they represent the majority of publicly traded real estate assets. Although focusing on a single industry might reduce the generality of our results, we believe that this restriction has several important advantages over including a broader set of acquirers: (i) it allows us to have a well-fitting but parsimonious return-generating model when determining 
abnormal returns; (ii) since we use Tobin’s $Q$ and accounting measures to evaluate long-term performance, we mitigate the distortions in $Q$ and financial ratios that arise from differing risk or growth opportunities; (iii) by using the same industry for both target and acquiring firms, we ensure that none of our transactions are for diversification motives; (iv) Comment and Schwert (1996) and Mitchell and Mulherin (1996) argue that merger waves are linked to broad economic factors, which can be industry-specific (this clustering is apparent in our data).

In addition, REIT mergers differ from the typical corporate merger in several important ways that lessen the importance of some of the classic corporate merger motives. These differences include: (i) Since a REIT’s governance structure (e.g., the high frequency of incorporation in management-friendly states such as Maryland) makes hostile acquisitions awkward, ${ }^{1}$ hostile takeovers are extremely rare in this industry. (ii) Real estate mergers are often motivated by a desire to acquire the management team. REIT analysts have recognized the value of target management in REIT mergers. Schalop (1998a, 1998b) observes that the most significant component of a company’s valuation multiple has consistently been the market's perception of management. Investors pay premiums for management teams perceived to be of high quality. An example is the following excerpt from the Duke Realty Annual Report of March 31, 1998.

In October we acquired Baur Properties in St. Louis and the R.L. Johnson Company in Minneapolis. Both are highly regarded organizations that bring to Duke not only high quality real estate but also talented and experienced management teams as well. In this regard, we are very pleased to now have Tee Baur heading the Duke operation in St. Louis and Robb Johnson in charge of our efforts in Minneapolis. The Farro, Baur and Johnson transactions benefit the Company far in excess of the value of the assets 
acquired. Combining the 20 or more years of market experience and relationship building of these teams with the efficiency of the Duke delivery system creates a situation where the whole truly exceeds the sum of the parts.

(iii) Public mergers of REITs are typically mergers of equals rather than a large firm acquiring a smaller target. ${ }^{2}$ (iv) It is unlikely that a REIT merger creates any monopolistic power since 75 percent of REIT income must come from "passive" real estate investments such as rents. $^{3}$

Perhaps the most significant of these advantages is the absence of hostile mergers in our sample. This characteristic is important because it eliminates the variations in performance arising from the differential pricing of hostile versus friendly mergers. ${ }^{4}$ It is clear that friendly mergers and mergers where target management is retained imply a less intensive level of bargaining and a more likely completion of the transaction than a hostile merger would. Removing hostile mergers reduces other possible complications. As the theoretical model of Schnitzer (1996) shows, the probability of the bidder adopting a hostile versus a friendly takeover increases as the synergy gains become less certain, which would be the case with the acquisition of management versus the acquisition of physical assets.

Our study supports the hypothesis that acquisition performance is linked to the difficulty in assessing the target’s value. Acquisitions of public firms have insignificant short-term abnormal returns. Acquisitions of private targets have positive and significant short-term abnormal returns. Furthermore, these returns are higher when the acquisitions include acquisition of the firm's management. As such, our work extends the short-term performance findings of Matsusaka (1993) of the positive benefits of retaining target management to cases where intra- 
industry mergers or public acquisitions are involved. An analysis of Tobin's $Q$ over the three years following the acquisition yields parallel results. In contrast to the findings of Chang (1998), Francis, Hasan, and Sun (2008), and Fuller et al. (2002), we find that our conclusions are robust to the type of financing (cash, stock, or a combination) used in the acquisition. Furthermore, it appears that disciplining managers is not as important a motive for acquisitions in our sample as it is in broader industry samples.

This study is organized as follows: the section "Background literature” overviews the related literature. The section "Data” describes our data set and statistical approach. The section “Empirical Results” presents our empirical analysis. The section “Conclusions” concludes.

\section{Background Literature}

One important fact has emerged from the extensive literature on mergers and restructurings: successful mergers are relatively rare events with the acquirer usually suffering poor returns, at the time of the announcement as well as in the short and the long-run. Early examples include Dodd (1980), Asquith (1983), and Eckbo (1983). Franks, Harris, and Titman (1991) find no significant abnormal returns in the three-year period following the completion of the merger. In a complementary study, Agrawal, Jaffe, and Mandelker (1996) find that neither firm size, nor beta, nor a slow adjustment of the market to the merger event explains this longrun, post-merger underperformance of acquirers. They also find that underperformance of acquirers is worse in non-conglomerate mergers than in conglomerate mergers. Loughran and Vijh (1997) show that the long-term returns of acquisitions financed by stock are significantly negative, but cash-financed transactions’ returns are significantly positive. ${ }^{5}$ Healy, Palepu, and Ruback (1992), show that the acquirer’s higher productivity leads to improvements in operating 
cash flow performance. ${ }^{6}$ Fee and Thomas (2004) also find evidence of increased productive efficiency in horizontal mergers. Conversely, Gosh (2001) using a sample of mergers from 1981 to 1995, finds no evidence of improved operating performance after a merger. Rosen (2005) shows that the long-term stock price performance of acquirers is lower for transactions done in hot merger or stock market periods. Finally, the interpretation of the stock price reaction to a takeover has been questioned (see, Hietala, Kaplan, \& Robinson, 2002; Krainer, 2012). In addition, Barber and Lyon (1997) and Brav (2000) describe the significant methodological difficulties associated with long-term performance studies based on stock prices.

Many reasons have been proposed to explain this inability to consistently achieve shareholder gains. These include: market efficiency (through large takeover premiums markets force acquirers to pay a fair price for the target); hubris (mergers are motivated by factors other than increasing shareholder value, see Roll, 1986); acquirers overestimate their ability to achieve projected synergies or economies of scale; etc.

Researchers have found, however, that mergers have been successful either when private firms are acquired (depending on how the merger is financed) or when the acquisition involves retaining management of the target, although conflicting evidence exists on the latter type of merger. Little or no research has examined the relative performance of firms acquiring targets with different degrees of transparency. The management literature (e.g., Chi, 1994; Coff, 1999, 2002) addresses the issue of the valuation uncertainty inherent in the acquisition of human capital-intensive firms. Human capital is naturally more difficult to value than are the physical assets of the firm, and the possibility of employee turnover presents a major risk to the acquirer. In addition, when the target's assets are hard to value, the acquirer must often rely on the target's management for critical information. Giammarino and Heinkel (1986) provide a theoretical 
development. Coff (1999) shows empirically that buyers are more likely to seek information from targets when the target is in a more information-intensive industry. Retaining the target's management makes it much more likely that this information is truthfully revealed.

\section{Acquisitions of Public versus Private Targets}

The analysis of acquisitions of private targets has been a recent area of research. However, comparisons between the performance of public and private acquisitions are complicated by the fact that analysts and investors more closely scrutinize public targets. Thus, they may be subject to takeover speculation, which could cause a run-up in the stock price and a higher final takeover premium. ${ }^{7}$ In addition, analysts have considerable data available when offering their opinions of the acquisition of a public firm. For private targets, in almost all cases the analyst is forced to rely on management's information, which makes it highly unlikely that the analyst is able to render a negative opinion on the proposed takeover.

Chang (1998) confirms the usual stock versus cash finding for acquisitions of publicly traded firms; i.e., a negative and significant price reaction for stock offers and a negative and insignificant price reaction for cash offers. For acquisitions of private firms however, he finds that, although the market reaction to the cash offers is insignificant, the market reaction to stock offers is positive and highly significant. He attributes these positive returns to a monitoring story; the emergence of a large blockholder improves the target’s efficiency. Fuller et al. (2002) using a time frame matching ours, find that the returns to acquisitions of private targets are significantly positive. Returns to acquirers of public targets, in contrast are negative and significant, especially when the transaction is financed by stock. Moeller et al. (2004), using dollar abnormal returns, ${ }^{8}$ also show that acquisitions of private firms have higher returns than public acquisitions. 
When the target has a significant non-tangible component (such as management), there can be substantial disagreement about target value. Kohers and Ang (2000) discuss the use of earnouts ${ }^{9}$ made by bidders to target shareholders as a way of binding target management. They estimate the announcement effect of an earnout of 1.36 percent. They find no significant differences arising from the acquirer's choice of financing mechanism. ${ }^{10}$

\section{Retention of Management}

Human capital (target management) is naturally more difficult to value ${ }^{11}$ than are the physical assets of the firm and the possibility of employee turn- over ${ }^{12}$ presents a major risk to the acquirer. The studies that analyze the issue of retained management do not reach a clear consensus on the value of retaining management. Matsusaka (1993) focuses on the motivation for mergers during and after the conglomerate merger wave of the late 1960s. The majority of the mergers examined involve privately owned targets and all mergers are in part stock-financed. He finds that acquirers realize positive announcement-period returns from inter-industry (diversifying) mergers and negative returns from intra-industry (related) mergers. ${ }^{13}$ He further finds that target management could be a key asset in a diversification acquisition, since the market reacts positively (negatively) to bidders that retain (remove) target management. This result suggests that acquirers who replace target management may either overpay, or overestimate their own abilities. Coff (2002) makes the point that human capital is a key aspect of many acquisitions and empirically demonstrates that it materially affects the probability of a transaction being completed. In contrast to Matsusaka (1993), Hubbard and Palia (1999) do not find a significant impact of management retention on acquirer returns in their analysis of the conglomerate mergers wave of the 1960 s. $^{14}$ 


\section{REIT Mergers}

REIT merger studies have reached no consensus on the benefits to the acquirer from the acquisition of the properties of another REIT or the REIT itself. These articles have tended to concentrate on the announcement effect rather than on short- and long-term performance.

Allen and Sirmans (1987), in contrast to the usual merger result, find a significant positive reaction to the acquirer's equity on the announcement date. They posit (but do not test) that this result is due to the acquirer's ability to identify superior management skill. In their sample almost all of the acquisitions are private firms. Glascock, Davidson, and Sirmans (1991) find that both buyers and sellers of real estate are more likely to receive a positive reaction to an acquisition announcement when they are acquiring property rather than a real estate division or a subsidiary. In contrast, McIntosh, Ott, and Liang (1995) find that the acquisition of real property by REITs does not result in positive wealth effects. Elayan and Young (1994) extend Allen and Sirmans’ (1987) examination of the sources of gains to target shareholders. They find that acquisitions that result in a change of control (i.e., if the acquisition results in the bidder's control of over 50 percent of the target's outstanding shares) earn larger excess returns than acquisitions where no change in control occurs.

Researchers have also found that the manner in which a real estate merger is financed has a significant impact on acquirer returns. Campbell, Ghosh, and Sirmans (2001) determine that the announcement effect of a REIT merger financed with stock is less negative than the corresponding announcement for a non-REIT merger. They attribute this result to the different signal conveyed by a REIT merger versus the typical corporate merger. Campbell, Ghosh, and Sirmans, analyzing stock-financed REIT acquisitions of private firms, find a significant positive 
relation between returns and the target lockout period, consistent with an information asymmetry story.

Ambrose, Ehrlich, Hughes, and Wachter (2000) study whether efficiency and informational gains result from increased size, brand imaging, or from geographic specialization. The authors find no benefits associated with REIT consolidation. ${ }^{15}$ Hardin and Wolverton (1999) address the issue of takeovers of private firms and conjecture that the rapid growth of REITs during the 1990s led them to overpay for their acquisitions. They find that acquisition of private firms yield poor results. ${ }^{16}$

Data

\section{Sample Design and Data}

We use Lexis-Nexis, NAREIT Statistical Digest, Securities Data Corporation (SDC), and SNL REIT databases to assemble a list of all REITs that are either the acquirer or the target in a merger from 1990 to 1999 . We obtain information on the price, return, and the number of shares outstanding from the Center for Research in Securities Prices (CRSP) database. Balance sheet and income statement data for each firm are obtained from Compustat and SNL REIT databases. We gather information on the merger characteristics from the proxy statements, 10Ks, and news articles from the Dow Jones News Retrieval and Lexis-Nexis. We verified each announcement date taken from SDC with the information in Lexis-Nexis and SNL REIT databases. We determine the financing structure of the merger by estimating the percentages of each financing mechanism used in each transaction.

We exclude REITs from our study if any of the following conditions apply: (i) the publicly traded company is not in the CRSP or Compustat database, (ii) the transaction value of 
the merger is below $\$ 2$ million, (iii) the acquirer or target is a foreign company, (iv) the exact announcement date could not be determined, or (v) the transaction was hostile. ${ }^{17}$ The resulting database of REIT mergers also captures the retention of target management. We classified a transaction as retaining management if the majority of the target's senior management takes on significant operating positions in the merged company. For example, we do not consider transactions in which the target's management is offered a seat on the board of directors as, in and of itself, signifying the retention of management. These awards are often given as compensation for being removed from an operating position.

\section{Estimation Approaches}

Our initial estimations focus on the market reaction and abnormal stock price performance when there is a merger announcement. In the second part, we calculate two performance measures. The first is Tobin's $Q$, which we define as

$$
Q=\frac{\text { Share price } \times \text { shares outstanging }+ \text { total assets }- \text { book equity }}{\text { Total assets }}
$$

The second measure is $A \operatorname{djRet}_{t}$, which is the holding-period return over t trading days less the return over the same period on a value-weighted index of seasoned REITs.

We designate the announcement date as $t=-1$ in event time. We denote the announcement period of interest, the two-day period that includes the announcement day and the day following as $t=(-1,0)$. We use standard event study methodology (following Brown \& Warner, 1985) and assume security returns are driven by a single-index market model, ${ }^{18}$ given by

$$
R_{i t}=\alpha_{i t}+\beta_{i} R_{m t}+\varepsilon
$$


where $R_{i t}$ is the return for security i on day $t, R_{m t}$ is the return on a benchmark index on day $t$, and $\alpha$ and $\beta$ are market model coefficients. We compute daily abnormal returns for each firm between $t=-3$ and $t=3$ in event time as

$$
A R_{i t}=R_{i t}-\left(\hat{a}_{i t}+\hat{e}_{i} R_{m t}\right)
$$

where $A R_{i t}$ is the abnormal return for firm $i$ on day $t$. The right-hand side is the realized return net of the estimated market model return. For each firm $i$, we estimate the market model coefficients using daily returns for the period $t=(-125,-4 ; 4,125)$. For each day $t=(-3,3)$, we determine the portfolio average abnormal returns as

$$
A A R_{t}=\frac{1}{N} \sum_{j=1}^{N} A R_{i t}
$$

where $N$ is the number of firms. We then compute the cumulative average abnormal return (CAAR) by summing the AAR over differing observation intervals. In the absence of abnormal performance, the expected values of AAR and CAAR are zero.

Test statistics for AAR and CAAR are based on the average standardized abnormal return $\left(A S A R_{t}\right)$ and the average standardized cumulative abnormal return $\left(A S C A R_{a, b}\right)$, where

$$
\begin{gathered}
\operatorname{ASAR}_{t}=\frac{1}{N} \sum_{j=1}^{N} \frac{A R_{i t}}{S_{i t}} \\
\operatorname{ASCAR}_{a, b}=\sum_{j=a 1}^{b} A S A R_{t}
\end{gathered}
$$

$S_{i t}$, the square root of firm $i$ 's estimated forecast variance, is given by

$$
S_{i t}=\sqrt{S_{i}^{2}\left(1+\frac{1}{L_{i}}+\frac{\left(R_{m t}-R_{m}\right)^{2}}{\sum_{k=1}^{L_{i}}\left(R_{m t}-R_{m}\right)^{2}}\right)}
$$


where $S_{i}^{2}$ is the residual variance for firm $i$ from the regression in Eq. (2); $L_{i}$ is the number of observations for firm $i$ in the comparison period; $R_{m t}$ is the real estate index return on day $t$ of the event period; $R_{m}$ is the mean real estate index return for the comparison period; $R_{m k}$ is the index return for day $k$ of the comparison period.

Assuming cross-sectional independence, $A S A R$, is asymptotically normal with mean zero and variance $1 / N$. The statistics $Z_{t}$ and $Z_{a, b}$ are unit normal. We use these statistics to test the null hypothesis that $A A R_{t}$ and $C A A R_{a, b}$ equal zero, where

$$
Z_{t}=\sqrt{N} \times A S A R_{t}
$$

and

$$
Z_{a, b}=\sqrt{N} \sum_{t=a}^{b} \frac{A S A R_{t}}{\sqrt{b-a-1}}
$$

We check the robustness of the event study results by using different windows for estimating market model parameters, and by adjusting for nonsynchronous trading using the estimation procedure described in Scholes and Williams (1977). Results in all cases are similar and are available on request.

\section{Empirical Results}

\section{Sample Characteristics}

Table 1 shows the distribution of acquisitions in our sample over the 11- year observation period. There is a substantial amount of clustering; of the 763 observations that have data available on the transaction size, 424 occur in the 1997-1998 window. Of the total sample, 156 involve the acquisition of property and management. These acquisitions are, on average, considerably smaller than the acquisitions of property only. In each of the years in which there are sufficient data, this difference is statistically significant. The distribution of transactions between acquisitions of property only and property and management is relatively stable over 
time. Transaction values increase quickly over the decade, beginning with an average target size of \$24.3 million in 1990 and ending with an average target size of \$356.3 million in 2000 .

\section{Insert Table 1}

Table 2 presents the financial characteristics of the acquiring REITs. The table shows that there are no important differences among the acquirers classified by acquisition type. This conclusion also holds if we break the sample into acquisitions of property versus property and management, or if we partition by financing mechanism. For example, the average value of acquirer assets ranges only from $\$ 879.7$ million in the cash — acquire property only category to $\$ 1,092$ million in the stock — acquire property only category. This similarity in asset values suggests that the following results will not be significantly influenced by differences in acquirer size or profitability.

\section{Insert Table 2}

\section{Event Study Results}

We find a significant positive announcement effect consistent with that of Allen and Sirmans (1987). Columns 2 and 3 of Table 3 show the CAAR values and associated significance statistics for various event time windows for the entire sample of 1,538 companies. The acquirer's CAAR for the two-day announcement period $t=(-1,0)$ is 1.48 percent, which is statistically significant at the 1 percent level. This figure implies that the announcement of a merger conveys positive information to the market. The CAAR for the period $t=(-1,1)$ is 1.73 percent, which is again significant at the 1 percent level. Consistent with market efficiency, the acquirer's CAAR for the period $t=(-5,-2)$ is 0.06 percent, which is not statistically significant $(Z$-value $=1.0)$. For the five days after the announcement $t=(1,5)$, the $C A A R$ is 0.31 percent and again is insignificant. 
From this set of 1,538 firms, only 763 have sufficient financial information to measure long-term performance. We use this sample in the remainder of our analysis. Columns 4 through 7 of Table 3 test the announcement effects separately for targets that are private before the announcement of the acquisitions and for all publicly traded targets. By partitioning our sample, we can see whether Allen and Sirmans’ (1987) findings are driven primarily by the acquisition of private firms since almost all of the acquisitions in their data are private firms. For takeovers of public firms (columns 6 and 7) the $C A A R$ values are all negative and insignificant except for the $(-3,3)$ window, which is significantly negative at the .10 level. In contrast, the announcement effects for acquisitions of private targets are all positive and significant in each of the observation periods containing the announcement date. The largest abnormal return, 1.76 percent, corresponds to the shortest observation window: $(-1,0)$. This finding is consistent with our underlying hypothesis: acquisitions of public firms, because of the difficulty in obtaining an informational advantage, should have a lower announcement effect than acquisitions of private targets. This result also provides a different interpretation of Allen and Sirmans' (1987) findings; their positive announcement effect result is influenced by the fact that their sample is almost exclusively private acquisitions.

\section{Insert Table 3}

To investigate whether our results are influenced by the method of financing the merger, we partition our sample into three groups in Table 4. The first group includes acquisitions that finance over 50 percent of the total transaction using cash; the second group contains acquisitions that finance over 50 percent of the total transaction using common stock. The third group consists of the remaining transactions, including many that use other funding sources, primarily debt. In our data set, these groups are roughly equal in size. For acquisitions of public 
targets the three groups contain 24, 36, and 34 observations, respectively. For the private acquisitions, the three groups contain 150, 142, and 132 observations, respectively.

The results summarized in Table 4 are quite different than those obtained by Chang (1998) or Fuller et al. (2002) and Burns, Francis, and Hasan (2007) for regular corporate mergers and Campbell et al. (2001) for REIT mergers. Rather than finding that stock transactions have a more positive announcement effect, we discover that the financing mechanism has little effect on the results reported in Table 3. For public targets, again the results are all insignificant. For private targets, the results are all positive and significant for time periods that include the announcement date. Furthermore, the magnitudes of the announcement effects are similar across each of the three financing mechanisms.

Insert Table 4

Insert Table 5

Table 5 presents the most important results in this study. It displays the announcement effects of acquirers given different degrees of transparency of the target firm: acquire the property only of a public target, acquire property and management of a public target, acquire property only of a private target, and finally acquire property and management of a private target. It also focuses more precisely on acquisitions of property only (607 transactions, 32 involving public targets) versus acquisitions of both property and management (156 transactions, 72 public). Our results for public versus private acquisitions are comparable to those obtained previously for more general samples of firms. In the short term, private acquisitions produce positive and significant returns, but public acquisitions produce negative and insignificant returns. For private acquisitions involving only property, we find that the announcement effects 
are positive and significant at the .10 level for the $(-1,0)$ and $(-1,1)$ performance windows. For public acquisitions involving only property, we find that for all performance windows the abnormal returns are negative and insignificant. When a firm acquires both the property and the management of private targets, the performance windows containing the announcement date have positive and significant returns. For firms that acquire the property and the management of public firms, the returns are similar, but significant only for $t=(-1,0)$ and $t=(-1,1)$.

These abnormal returns suggest that acquisitions that include management earn more positive abnormal returns for both private and public acquisitions. Thus, our data support our basic hypothesis on the ordering of these four classes of transactions. Our results differ from Matsusaka (1993) since we find that a premium can exist for mergers within the same industry ("related” acquisitions) if target management is retained. However, our finding that including target management can yield positive abnormal returns for public acquisitions is in agreement with Matsusaka (1993) since his study deals primarily with private acquisitions.

To verify that our results in Table 5 do not depend on the financing mechanism we look at acquisitions of property versus property and management by financing mechanism in Table 6 . As noted in the first section, previous research concerning the value of stock versus cash financing is inconclusive. For each of the financing mechanism we find results consistent with Table 5. Transactions involving management have higher returns, in both magnitude and statistical significance, than do transactions involving only property. The abnormal returns for acquisitions of property only are weakly significant, although almost all are positive. For the observation windows $t=(-1,0)$ and $t=(-1,1)$, the announcement effects are positive and significant at the .05 level for acquisitions of property and management. These announcement 
effects show that one of our key results, that acquisitions involving management produce higher announcement effects, is robust to the acquirer's choice of financing mechanism.

A further issue is whether or not the size of the acquisition influences the announcement effect. This is indirectly a test of the Hubbard and Palia (1999) finding that positive gains can occur when targets are capital constrained. Since relatively few of our acquirers have debt ratings, and those that do have, with almost no exceptions a BBB-rating, we use target size as a proxy for access to capital. We partition the 104 public targets in our sample into acquisitions of property only versus property and management in Table 7. We then split each of these groups into halves based on target size. The abnormal returns over each of the performance windows are similar for small and large targets, although, as we expected, the returns are generally slightly higher for larger targets. This result suggests that the target's access to capital does not drive our main results.

Insert Table 6

\section{Insert Table 7}

\section{Long-Term Performance}

We next investigate whether our short-run performance results are valid in the longer term. We use Tobin's $Q$ as our primary performance metric; return on assets (ROA) and return on equity (ROE) serve as robustness checks. For all acquirers in the sample, Table 8 shows that the Tobin's $Q$ of the acquiring REIT increases in the two years following the merger and then levels off. Operating performance (as measured by return on assets, return on book equity, and sales to assets) increases in each of the first three years following the acquisition. These $Q$ values 
suggest that on average, the long-term operating performance of acquirers improves after the transaction.

Insert Table 8

Insert Table 9

Table 9, rows 3 and 4, show the Tobin's $Q$ of transactions by property only versus property and management. In each of years one through three after the merger, Tobin's $Q$ is higher for acquisitions that include management. In the year following the acquisition, the $Q$ for acquisitions of only property is 1.11 compared with 1.44 for acquisitions of property and management. This difference increases over the two following years. Rows 5 and 6 of Table 9 display the same comparison for transactions involving private versus public targets. Again, we see that in each of the three years after the merger, Tobin's $Q$ is higher for private targets. In the year following the acquisition, the $Q$ for acquisitions of public targets is 1.12 compared with 1.31 for private targets. Unlike the prior result, this difference does not increase, but instead remains constant in the following years. These observations are consistent with those obtained for shortterm abnormal performance. However, the long-term results should be interpreted with some caution. The differences are small relative to the high estimated standard deviations so that these differences are not statistically significant. Secondly, the Qs of the acquirers in the year prior to the merger differ across the various types of targets, ranging from 0.87 for acquirers of public firms to 1.10 for acquirers of property and management. The average change in $Q$ from the year prior to three years after is 0.27 for property only, 0.92 for property and management, 0.42 for private targets, and 0.39 for public targets. 
To verify that the conclusions of Table 9 are robust to the financing of the transaction, Table 10 looks at Tobin's $Q$ one and three years after the merger according to the financing mechanism and type of acquisition. In each case, although the figures are much closer for transactions using a combination of financing methods, private acquisitions have higher Qs than do public transactions; acquisitions involving management have a higher $Q$ than do acquisitions of only property. The $Q$ values one year after the merger are $0.67,0.21$, and -0.01 higher for purchases of property versus property and management for cash, stock, and mixed transactions, respectively. The $Q$ values three years after the merger are $0.57,0.15$, and 0.24 higher for purchases of property versus property and management for cash, stock, and mixed transactions, respectively. The $Q$ values one year after the merger are $0.81,0.37$, and 0.01 higher for private targets versus public targets and management for cash, stock, and mixed transactions, respectively. The $Q$ values three year after the merger are $1.00,0.46$, and 0.04 higher for private versus public targets for cash, stock, and mixed transactions, respectively. Thus, the advantages of private versus public and retaining management are substantial and appear to be greater over the longer horizon.

Insert Table 10

Insert Table 11

To further check the robustness of these results, we replace Tobin’s $Q$ with return on assets (ROA) and return on equity (ROE) as the performance measure. The first row of Table 11 shows the average ROA over the entire sample for the merger year and one to five years after the merger. Overall, the ROA rises from the merger year value of 4.28 to a peak value of 5.59 four years after the merger. The average increase in $Q$ from the merger year to the year following is 
substantial, 0.64, again suggesting that overall these mergers are beneficial to the acquirer. We also observe this increase in each of the four subgroups. The values are $0.78,0.78,0.66$, and 0.86 for property only, property and management, private, and public targets, respectively. The highest ROA in the post-merger year, 5.45, corresponds to acquisitions of both property and management. The lowest value is 4.81 for acquisitions of property only. After the first postmerger year, the increases in $Q$ are much smaller for each of the four groups. As in the prior table, these results are influenced by the fact that the ROAs of the acquirers in the year prior to the merger differ substantially across the various types of targets, ranging from 2.97 for acquirers of public firms to 4.96 for acquirers of property and management. The average change in ROA from the year prior to three years after is 1.38 for property only, 0.83 for property and management, 1.07 for private targets, and 2.37 for public targets. Thus while acquisitions of property and management result in the highest average ROA in each of the years following the merger, these acquirers had substantially higher ROAs prior to the merger.

Insert Table 12

Table 12 repeats this analysis using ROE as the performance measure. Consistent with the prior results where we measure performance by $Q$, private acquisitions have a higher postmerger ROE than do public transactions and acquisitions involving management have a higher post-merger ROE than do acquisitions of only property. Again however, these results are confounded by the observation that the performance of firms acquiring property only and acquiring public firms was weaker prior to the merger. While this observation makes the interpretation of the long-term ROA and ROE of acquirers less precise, it hints at an interesting area for potential future research. Tables 11 and 12 suggest that better performing REITs tend to 
acquire private targets and to retain management. Consistent with a hubris theory, managers who may be overconfident of their ability tend to acquire public targets and only property.

\section{Insert Table 13}

Finally, to gauge the long-term impact of retaining management on the acquirer's $Q$, Table 13 reports the results of a regression that uses $Q$ in years one through three after the transaction as the dependent variable. The independent variables are the log of assets, the salesto-assets ratio, leverage, and a dummy for the retention of management. The F-statistics of the resulting regressions are all significant at the .01 level and the adjusted $R^{2}$ s average about 16 percent, and decline with a lengthening horizon. In each of the regressions the dummy coefficient for management retention is positive and significant at the .05 level, indicating that the retention of management has a significant impact on the acquirer's long-term performance. This result reinforces our hypothesis that acquirers can have an informational advantage in the acquisition and retention of a target's management. Our finding also tends to support the “managerial synergy” theory that management of the acquirer wanted to work with target management. This result further suggests that the role of mergers as a way of disciplining management may not be a significant factor in our data.

\section{Conclusions}

Our paper investigates the merger hypothesis that short-run and long-term performance of the acquirer is higher the less transparent (more difficult to value) the target's assets. Assets are harder to value when the acquisition involves human capital, most notably target management and/or when the firm to be acquired is private. Human capital (target management) is naturally more difficult to value than are the physical assets of the firm and the possibility of 
employee turnover presents a major risk to the acquirer. Thus, the highest returns should come from acquiring the management and assets of a private company. Conversely, the lowest returns should result from acquiring the physical assets of a publicly traded firm.

To test this hypothesis, we examine a total of 1,538 friendly acquisitions by public REITs between January 1990 and December 2000. To make our measures of performance less sensitive to variation due to industry differences and to avoid diversifying mergers, we use only acquisitions within the real estate area. Our empirical analysis supports the hypothesis that acquisition performance is linked to the difficulty in assessing the target's value. Using the standard event study approach with a REIT index as the benchmark to measure short-term reactions, we find that acquisitions of public firms have negative and insignificant short-term abnormal performance. Acquisitions of private targets have positive and significant short-term abnormal performance. Abnormal returns are higher when the acquisitions of private firms include acquisition of the firm's management. These results are paralleled when we analyze the acquirer's $Q$ over the three years following the merger. Our conclusions are robust to the type of financing (cash, stock, or a combination) used in the acquisition. In addition, when we regress the $Q$ of an acquirer on a set of REIT characteristics we find that a dummy variable representing the retention of management is positive and significant. These findings suggest that for our set of acquisitions, takeovers are not extensively used as a disciplining measure. 


\section{Notes}

1. See Hartzell, Kallberg, and Liu (2003) for an analysis of the impact of REIT governance structure on firm valuation at the IPO date. Daines (2001) discusses the positive impact on Q stemming from incorporation in Delaware. This fact has been often observed in the popular press. For example, as Porter (1997) cites: there will be three types of REIT M\&A. There will be the truly friendly one, the somewhat friendly deals — the hostile ones that become 'friendly' once the takeover price is raised to the target's satisfaction and management is brought on board — and the outright hostile ones. The majority of REIT deals will be consensual by the time they are public.”

2. Hasan, Kallberg, and Liu (2002) find that although the average size of public targets grew rapidly during the 1990s from an average of about $\$ 43$ million in the beginning of the decade to averages approaching $\$ 1$ billion at the end of the decade, the size of the target relative to its acquirer remained relatively constant at about 37 percent. For more details on REIT M\&As, see Ratcliffe and Dimovski (2012).

3. Allen and Sirmans (1987) analyze the relevance of classic corporate merger motives to REITs.

4. Schwert (2000) finds that the takeover premia in a hostile transaction are between 9 and 15 percent higher than in a friendly transaction.

5. Schlingemann (2004) examines the source of takeover capital (rather than the payment mechanism) and finds positive announcement-period returns only for acquirers using equity financing.

6. See also Healey, Palepu, and Ruback (1997).

7. The relation between run-up and merger premium is studied in Schwert (1996). 


\section{See Malatesta (1983).}

9. Earnouts, which offer payments conditional on the merged firm’s future performance, help resolve agency and informational asymmetry problems, since, presumably, only high-value managers will agree to defer part of the merger premium. Kohers and Ang analyze 938 mergers that include earnouts: 620 private (with an average value of \$10.4 million); 275 were divested subs (with an average value of $\$ 27.2$ million). In our data set, there are relatively few, if any earnouts. In a conversation with Robin Panovka, an attorney with Wachtel, Lipton in New York City, who specializes in REIT mergers, he also noted that earnouts aren't typically found in REIT merger deals although the merger consideration can includes contingent value rights (CVRs) but these are very difficult to value and are accorded little weight in the merger.

10. The literature dealing with stock financing as an incentive mechanism is also relevant here; see, i.a., Osano (2004).

11. Giammarino and Heinkel (1986) provide a theoretical development.

12. Martin and McConnell (1991) show that tender offers (typically a criterion for classifying a merger as hostile) lead to high levels of management turnover. Shivdasani (1993) also documents the high levels of management turnover following a hostile takeover. As Morck, Shleifer, and Vishny $(1988,1989)$ suggest, hostile mergers are typically disciplinary, while friendly mergers are generally motivated by synergy gains.

13. Matsusaka (1993) defines a “diversification acquisition” as one in which the acquirer and the target have different two-digit SIC codes. If both the acquirer and target have the same twodigit SIC code then he defines this as a "related acquisition."

14. In their sample over 75 percent of the acquisitions retained management. 
15. This finding is in direct conflict with the popular press and well-known REIT managers, such as Sam Zell, who have extolled REIT mergers as a way to achieve economies of scale. They assert that larger REITs have better access to funds, lower overhead costs, etc.

16. See Corgel, McIntosh, and Ott (1995), Choi, Francis, and Hasan (2010), Ongena and Penas (2009), and Ratcliffe and Dimovski (2012) for related discussion.

17. Eight of the transactions in our sample were flagged by SDC as hostile, i.e., involving a tender offer, but public sources did not confirm these classifications. Rerunning our analysis omitting these eight observations leads to no relevant differences in our results.

18. The issue of the efficiency of single- versus multiple-factor model in explaining REIT returns is analyzed in Kallberg, Liu, and Trzcinka (2000). They find that a single-factor model using a REIT index can explain approximately 85 percent of REIT returns and that the marginal contribution of additional factors (such as the Fama—French factors) is minimal. 


\section{Acknowledgments}

We would like to thank our discussant Ron Donohue and participants at the AFA meetings for very helpful comments on an earlier draft of this paper. We are also grateful to David Brown, William Gentry, Atul Gupta, Kose John, Chris Mayer, Robin Panovka, and Paolo Pasquariello for helpful discussions. We would also like to thank the Stern School and the Real Estate Institute of New York University for funding, Erik Kallberg for research assistance, and Sandra Moore for editorial assistance. The usual disclaimer applies. 
Table 1. Frequency Distribution.

\begin{tabular}{|c|c|c|c|c|c|c|}
\hline Year & $\begin{array}{l}\text { Total Number of } \\
\text { Acquisitions }\end{array}$ & $\begin{array}{c}\text { Transaction Mean } \\
\text { Value }\end{array}$ & $\begin{array}{c}\text { Number of } \\
\text { Property Only }\end{array}$ & $\begin{array}{c}\text { Transaction Mean } \\
\text { Value }\end{array}$ & $\begin{array}{c}\text { Number of Property \& } \\
\text { Management }\end{array}$ & $\begin{array}{c}\text { Transaction Mean } \\
\text { Value }\end{array}$ \\
\hline 1990 & 11 & 24.3 & 11 & 24.3 & 0 & - \\
\hline 1991 & 10 & 7.7 & 7 & 8.4 & 3 & 6.7 \\
\hline 1992 & 21 & 41.6 & 19 & 27.9 & 2 & $172.0^{\star \star}$ \\
\hline 1993 & 37 & 21.6 & 34 & 19.2 & 3 & $48.9^{\star \star}$ \\
\hline 1994 & 59 & 29.0 & 48 & 13.5 & 11 & $96.5^{\star \star}$ \\
\hline 1995 & 49 & 111.7 & 32 & 36.7 & 17 & $252.9^{\star \star}$ \\
\hline 1996 & 77 & 116.1 & 55 & 69.9 & 22 & $231.6^{\star \star}$ \\
\hline 1997 & 212 & 227.7 & 167 & 115.8 & 45 & $643.0^{\text {*ᄎ }}$ \\
\hline 1998 & 212 & 181.9 & 181 & 100.8 & 31 & $655.6^{\star \star}$ \\
\hline 1999 & 58 & 164.5 & 42 & 63.9 & 16 & $428.5^{\star \star}$ \\
\hline 2000 & 17 & 356.3 & 11 & 231.7 & 6 & $584.8^{\star \star}$ \\
\hline
\end{tabular}

The table presents the basic distribution of our sample over the 11-year observation period. The transaction values are average of the group in millions. Here, ${ }^{\star \star \star},{ }^{\star *}$, and ${ }^{*}$ indicate the differences of mean transaction values between the "Acquire Property Only" and "Acquire Property and Management" groups are significant at the 1,5 , and 10 percent significance levels, respectively, using a two-tailed test. 
Table 2. Acquirer Descriptive Statistics.

\begin{tabular}{|c|c|c|c|c|c|c|c|c|}
\hline & \multicolumn{4}{|c|}{ Acquire Property Only } & \multicolumn{4}{|c|}{ Acquire Property and Management } \\
\hline & Assets & Sales & Equity & Net income & Assets & Sales & Equity & Net income \\
\hline Private & 996.24 & 255.38 & 542.76 & 46.20 & $1053.81^{\star \star}$ & $271.20^{\star}$ & 529.21 & 51.40 \\
\hline Public & 1011.93 & 256.77 & 550.92 & 40.28 & 1024.02 & 264.41 & $578.22^{\star}$ & 45.21 \\
\hline Stock & 1092.06 & 294.27 & 547.21 & 46.87 & 1081.55 & 283.62 & $568.16^{\star}$ & $57.80^{\star}$ \\
\hline $\begin{array}{l}\text { Assuming debt, } \\
\text { other methods } \\
\text { and/or mixed }\end{array}$ & 973.29 & 244.38 & 532.76 & 44.81 & $1031.72^{\star \star \star}$ & $226.57^{\star \star}$ & $520.26^{\star \star}$ & 49.23 \\
\hline
\end{tabular}

methods

The table gives the general financial characteristics of the acquiring REITs. All figures are in millions and are measured at the time of the acquisition. Equity is the market value of equity. Here, ${ }^{\star \star \star},{ }^{\star \star}$, and ${ }^{*}$ indicate the differences of mean transaction values between the "Acquire Property Only" and "Acquire Property and Management" groups are significant at the 1,5, and 10 percent significance levels, respectively, using a two-tailed test. 
Table 3. Merger Announcement Effects (Full Sample).

\begin{tabular}{|c|c|c|c|c|c|c|}
\hline \multirow[t]{2}{*}{ Window } & \multicolumn{2}{|c|}{ All Targets (Full Sample, $N=1,538$ ) } & \multicolumn{2}{|c|}{$\begin{array}{l}\text { Private Target (Book Value Subsample, } \\
\qquad N=659)\end{array}$} & \multicolumn{2}{|c|}{ Public Target (Full Sample, $N=104$ ) } \\
\hline & CAAR (\%) & Z-statistic & CAAR (\%) & Z-statistic & CAAR (\%) & Z-statistic \\
\hline$(-5,-2)$ & 0.06 & 1.02 & 0.59 & 1.48 & 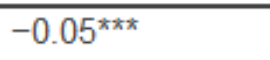 & 0.15 \\
\hline$(-1,0)$ & 1.48 & $3.99^{\star \star \star}$ & 1.76 & $3.01^{\star \star \star *}$ & $-0.42^{\text {*ᄎ }}$ & 0.95 \\
\hline$(-1,1)$ & 1.73 & $4.81^{\star \star \star}$ & 1.21 & $3.47^{\star \star \star}$ & $-0.47^{\star \star \star}$ & 1.21 \\
\hline$(-3,3)$ & 1.26 & $2.50^{\star \star}$ & 0.85 & $2.01^{\star \star}$ & $-0.83^{\star \star \star}$ & $1.86^{\star}$ \\
\hline$(1,5)$ & 0.31 & 0.84 & 0.74 & 1.42 & -0.87 & 0.91 \\
\hline
\end{tabular}

The table reports the cumulative average abnormal returns (CAAR) to merger announcements in the real estate industry over the 1990-2000 period. All acquirers are publicly traded firms; targets include both public and private firms. We report the entire sample of 1,538 mergers as "all targets." Since detailed financial information is available for only 763 transactions, we base subsequent estimations and analyses on this subsample, which includes 659 private and 104 public targets. Here, ${ }^{\star \star \star},{ }^{\star \star}$, and ${ }^{\star}$ indicate that CAAR for the given period is significantly different from zero at the 1, 5, and 10 percent significance levels, respectively, using a two-tailed test. We compute abnormal returns using a single-factor model with a REIT index. Also, ${ }^{\star \star *},{ }^{\star \star}$, and ${ }^{\star}$ indicate the significance of $t$-statistics associated with differences of average abnormal return between public versus private groups. 
Table 4. Merger Announcement Effects and Primary Financing Mechanism.

\begin{tabular}{|c|c|c|c|c|c|c|c|}
\hline \multirow{2}{*}{$\begin{array}{l}\text { Primary Financing } \\
\text { Source }\end{array}$} & \multirow{2}{*}{ Window } & \multicolumn{3}{|c|}{ Private Target } & \multicolumn{3}{|c|}{ Public Target } \\
\hline & & $N$ & CAAR (\%) & Z-statistic & $N$ & CAAR (\%) & Z-statistic \\
\hline & $(-1,0)$ & 150 & 0.81 & $2.48^{\star \star}$ & 34 & $-0.37 ! !$ & 0.48 \\
\hline & $(-3,3)$ & 150 & 0.83 & $2.02^{\star \star}$ & 34 & $-0.12 ! ! !$ & 0.81 \\
\hline & $(1,5)$ & 150 & 0.72 & 0.80 & 34 & $-0.07 ! ! !$ & 0.63 \\
\hline & $(-5,-2)$ & 142 & 0.61 & 0.61 & 36 & $-0.13 ! ! !$ & 0.42 \\
\hline \multirow[t]{4}{*}{ Stock } & $(-1,1)$ & 142 & 0.95 & 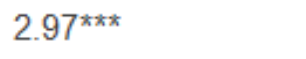 & 36 & $0.05 ! ! !$ & 0.39 \\
\hline & $(-3,3)$ & 142 & 0.60 & 1.45 & 36 & $-0.81 !$ & $1.97^{\star \star}$ \\
\hline & $(1,5)$ & 142 & 0.31 & 0.35 & 36 & $-0.63 ! !$ & 1.43 \\
\hline & $(-5,-2)$ & 132 & 0.14 & 0.61 & 34 & $-0.32 !$ & 0.29 \\
\hline \multirow{2}{*}{$\begin{array}{l}\text { Assuming debt, other } \\
\text { methods and/or mixed } \\
\text { methods }\end{array}$} & $(-1,0)$ & 132 & 1.02 & $2.98^{\star \star \star}$ & 34 & $0.44 ! ! !$ & 0.76 \\
\hline & $(-1,1)$ & 132 & 0.97 & $3.23^{\star \star \star}$ & 34 & $0.13 ! ! !$ & 1.60 \\
\hline
\end{tabular}

The table reports the cumulative average abnormal returns (CAAR) to merger announcements in the real estate industry over the 1990-2000 period according to the primary source of financing used in the merger. Here "primary" means that at least $50 \%$ of the payment method is based on the given financing mechanism. $N$ denotes the sample size for each source of financing. We obtain exact financing sources for 426 of the 659 private targets and 94 of the 104 public targets. Here, ${ }^{\star \star \star},{ }^{\star \star}$, and ${ }^{*}$ indicate that CAAR for the given period is significantly different from zero at the 1,5 , and 10 percent significance levels, respectively, using a two-tailed test. We compute abnormal returns using a single-factor model with a REIT index. Also, !!!, !!, and ! indicate the significance of $t$-statistics associated with differences of average abnormal return between public versus private groups. 
Table 5. Merger Announcement Effects and Acquisition Type.

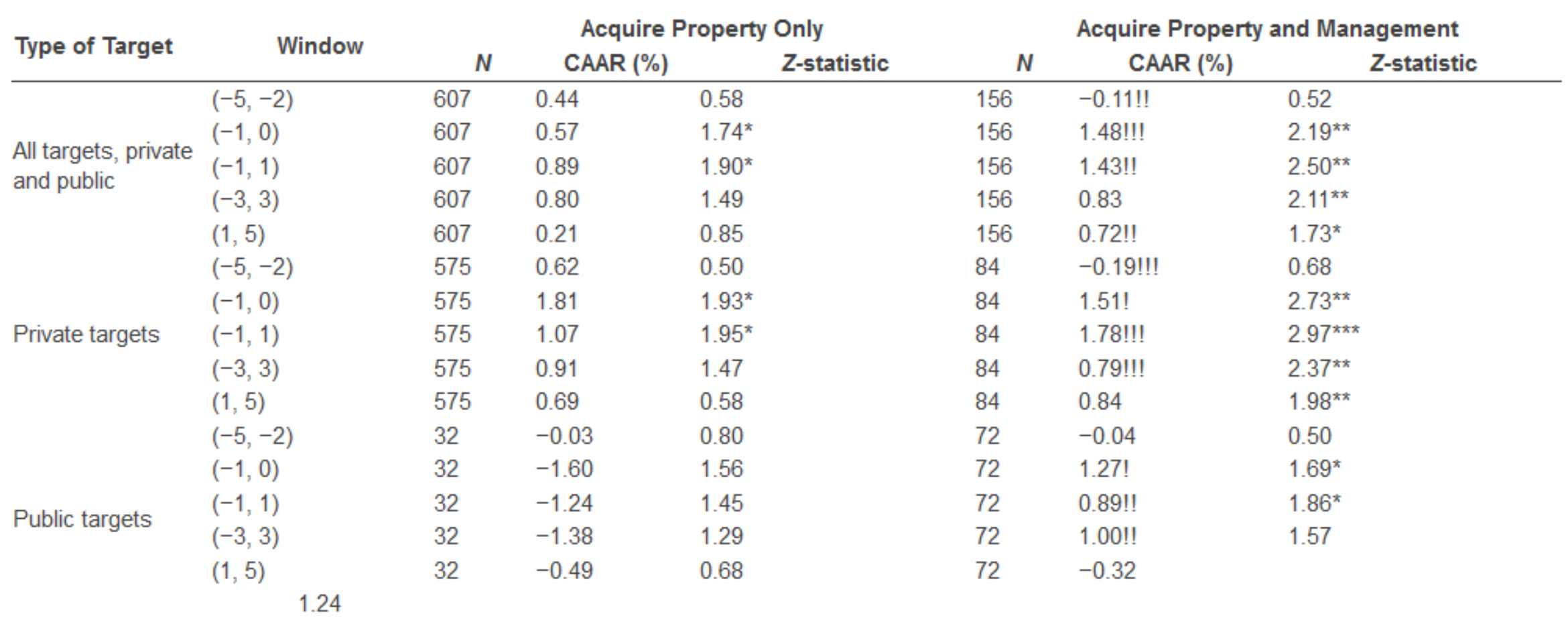

Note: The cumulative abnormal return differences between the private and public targets are significant at least at the 5 percent significance level in all estimated windows above, except for the $(-3,3)$ windows, where the differences between the two types of targets are significantly difference at the 10 percent level.

The table reports the cumulative average abnormal returns (CAAR) to merger announcements in the real estate industry over the 1990-2000 period according to the target classification. Transactions are partitioned into cases where the acquirer purchases only the some or all of the assets of the target firm, e.g., a property portfolio, or where real assets and the management of the firm are purchased. $N$ denotes the sample size. Here, ${ }^{\star \star \star},{ }^{\star \star}$, and ${ }^{\star}$ indicate that CAAR for the given period is significantly different from zero at the 1,5, and 10 percent significance levels, respectively, using a two-tailed test. We compute abnormal returns using a single-factor model with a REIT index. Also, !!!, !!, and ! indicate the significance of $t$-statistics associated with differences of average abnormal return between the acquire property and acquire property and management groups 
Table 6. Merger Announcement Effects, Acquisition Type, and Primary Financing Mechanism.

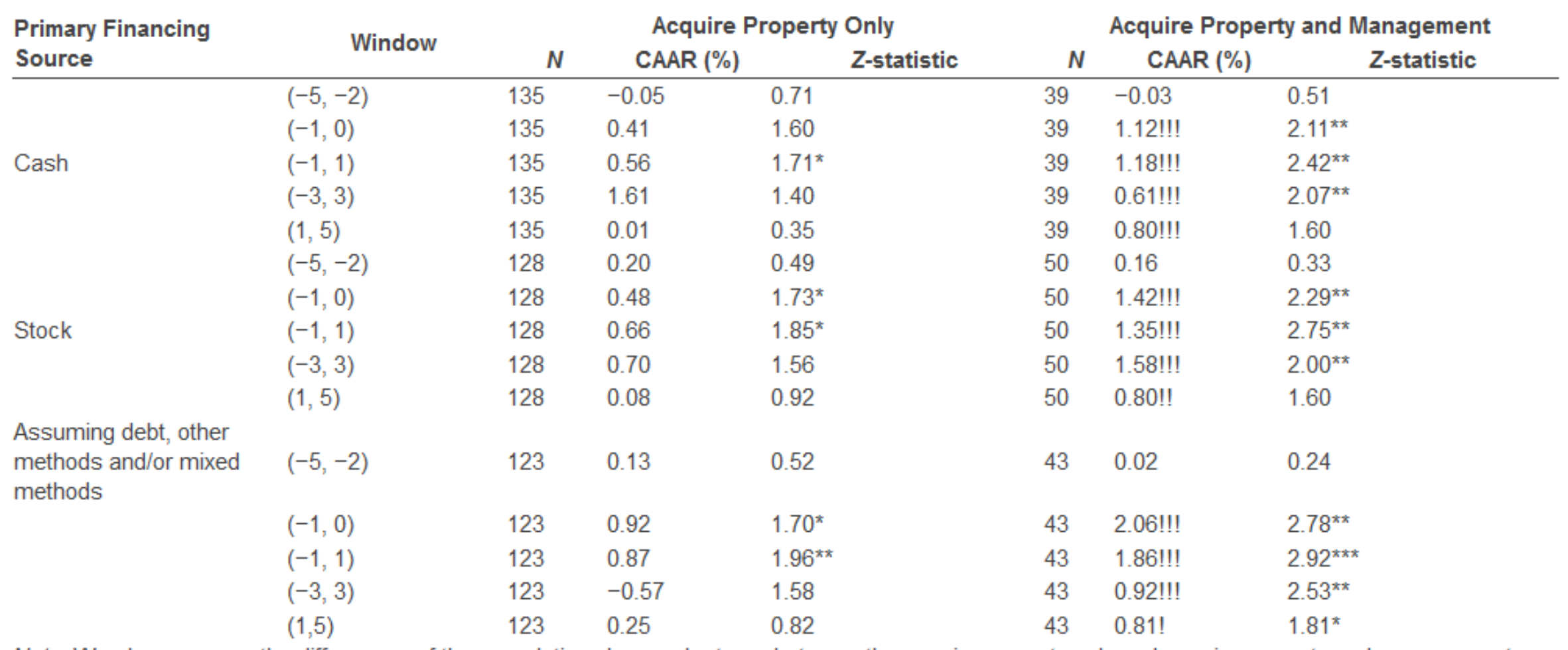

Note: We also measure the differences of the cumulative abnormal returns between the acquire property only and acquire property and management groups. Among the reported 15 possible pairs of CAAR estimations, in each case (except for the CAAR differences in window $(-5,-2)$ in all three types of financing), the mean differences between the two groups are significantly different at least at the 5 percent significance level.

The table reports the cumulative average abnormal returns (CAAR) to merger announcements in the real estate industry over the 1990-2000 period according to the target classification and primary source of financing used in the merger. $N$ denotes the sample size. Here, ${ }^{* \star *}$, ${ }^{* *}$, and ${ }^{*}$ indicate that CAAR for the given period is significantly different from zero at the 1,5, and 10 percent significance levels, respectively, using a two-tailed test. We compute abnormal returns using a single-factor model with a REIT index. Also, !!!, !!, and ! indicate the significance of $t$-statistics associated with differences of average abnormal return between the acquire property and acquire property and management groups. 
Table 7. Responses of Prices to Merger Announcements According to Acquisition Type.

\begin{tabular}{|c|c|c|c|c|c|c|c|}
\hline \multirow{2}{*}{ Type of Target } & \multirow{2}{*}{ Window } & \multicolumn{3}{|c|}{ Acquire Property Only } & \multicolumn{3}{|c|}{ Acquire Property and Management } \\
\hline & & $N$ & CAAR (\%) & Z-statistic & $N$ & CAAR (\%) & Z-statistic \\
\hline \multirow{5}{*}{$\begin{array}{l}\text { Public targets - } \\
\text { Small }\end{array}$} & $(-5,-2)$ & 16 & -0.01 & 0.45 & 36 & -0.02 & 0.61 \\
\hline & $(-1,0)$ & 16 & 0.95 & 1.08 & 36 & $1.40 !$ & 1.60 \\
\hline & $(-1,1)$ & 16 & 1.00 & 1.50 & 36 & $1.52 ! !$ & $1.74^{\star}$ \\
\hline & $(-3,3)$ & 16 & 0.74 & 1.13 & 36 & $1.08 !$ & 1.43 \\
\hline & $(1,5)$ & 16 & -0.40 & 0.58 & 36 & $0.24 ! !$ & 0.89 \\
\hline \multirow{5}{*}{$\begin{array}{l}\text { Public targets - } \\
\text { Large }\end{array}$} & $(-5,-2)$ & 16 & -0.03 & 1.06 & 36 & -0.09 & 0.38 \\
\hline & $(-1,0)$ & 16 & 1.11 & $1.67^{*}$ & 36 & 1.07 & 1.65 \\
\hline & $(-1,1)$ & 16 & 1.09 & 1.42 & 36 & $1.98 ! ! !$ & $1.68^{*}$ \\
\hline & $(-3,3)$ & 16 & 0.83 & 1.29 & 36 & $1.03 !$ & 1.38 \\
\hline & $(1,5)$ & 16 & -0.49 & 0.68 & 36 & $0.32 ! !$ & 1.30 \\
\hline
\end{tabular}

Note: The cumulative abnormal return differences are insignificant between the private and public targets in all but 2 of the 20 pairs of comparisons. The differences in windows $(-1,0)$ and $(-1,1)$ between the public-private groups (acquire property and management columns) are significantly different at 10 percent significance level.

The table shows the cumulative average abnormal returns (CAAR) to merger announcements according to the target classification and size of target. We only analyze publicly traded targets. $N$ denotes the sample size. Here, ${ }^{\star \star \star},{ }^{\star \star}$, and * indicate that CAAR for the given period is significantly different from zero at the 1,5, and 10 percent significance levels, respectively, using a two-tailed test. We compute abnormal returns using a single-factor model with a REIT index. Also, !!!, !!, and ! indicate the significance of $t$-statistics associated with differences of average abnormal return between the acquire property and acquire property and management groups. 
Table 8. Long-Term Performance of the Acquirer.

\begin{tabular}{|c|c|c|c|c|c|}
\hline $\begin{array}{l}\text { Acquirers' Types and } \\
\text { Characteristics }\end{array}$ & $\begin{array}{c}1 \text { Year Before } \\
\text { Merger }\end{array}$ & $\begin{array}{c}\text { Merger Year (Calendar } \\
\text { Year) }\end{array}$ & $\begin{array}{c}\text { One Year After } \\
\text { Merger }\end{array}$ & $\begin{array}{c}\text { Two Years After } \\
\text { Merger }\end{array}$ & $\begin{array}{c}\text { Three Years After } \\
\text { Merger }\end{array}$ \\
\hline \multirow{2}{*}{ Tobin's Q } & $1.01^{\star}$ & 1.18 & 1.22 & $1.53^{\star \star}$ & $1.49^{\star \star}$ \\
\hline & $(1.26)$ & $(1.52)$ & $(1.09)$ & $(1.46)$ & $(1.35)$ \\
\hline \multirow{2}{*}{ Return on assets } & 4.29 & 4.17 & $4.96^{\star \star}$ & $5.34^{\star \star \star *}$ & $5.46^{\text {*** }}$ \\
\hline & (3.61) & $(4.08)$ & (3.51) & $(3.44)$ & $(1.92)$ \\
\hline \multirow{2}{*}{ Return on equity } & $8.16^{\star}$ & 7.46 & $8.01^{*}$ & $8.92^{\star \star \star}$ & $9.45^{\star \star \star}$ \\
\hline & $(6.28)$ & $(4.80)$ & $(3.60)$ & $(4.16)$ & $(8.6)$ \\
\hline \multirow{2}{*}{ Sales to assets } & $18.05^{\star}$ & 15.79 & 17.18 & $18.12^{\star \star \star}$ & $21.93^{\star \star \star}$ \\
\hline & (18.13) & $(21.03)$ & (19.78) & $(15.56)$ & $(19.89)$ \\
\hline \multirow{2}{*}{ Assets } & $751.13^{\star \star}$ & 894.21 & $962.34^{\star}$ & $1041.55^{\star \star}$ & $1151.03^{\star \star \star}$ \\
\hline & $(1127.05)$ & $(1023.91)$ & $(863.46)$ & $(814.56)$ & $(944.31)$ \\
\hline Number of observations & 763 & 763 & 763 & 744 & 661 \\
\hline
\end{tabular}

The table reports the means and standard deviations (in parentheses) for several acquirer performance measures, including Tobin's $Q$, the return on assets, and the return on equity as well as a measure of asset productivity, sales to assets, and total asset size. The number of observations is given in the bottom row. Here, ${ }^{\star \star \star},{ }^{\star \star}$, and ${ }^{*}$ indicate the differences of mean in a non-merger year relative to the mean statistics in the merger year at the 1,5 , and 10 percent significance levels, respectively. 
Table 9. Tobin’s Q by Acquisition Type.

\begin{tabular}{|c|c|c|c|c|c|}
\hline Acquirers' Types and Characteristics & $\begin{array}{c}\text { One Year Before } \\
\text { Merger }\end{array}$ & $\begin{array}{c}\text { Merger Year (Calendar } \\
\text { Year) }\end{array}$ & $\begin{array}{c}\text { One Year After } \\
\text { Merger }\end{array}$ & $\begin{array}{c}\text { Two Years After } \\
\text { Merger }\end{array}$ & $\begin{array}{c}\text { Three Years After } \\
\text { Merger }\end{array}$ \\
\hline \multirow{3}{*}{ All sample } & $1.01^{\star}$ & 1.18 & 1.22 & $1.53^{\star \star}$ & $1.49^{\star \star}$ \\
\hline & $(1.26)$ & $(1.52)$ & $(1.09)$ & $(1.46)$ & $(1.35)$ \\
\hline & 763 & 763 & 763 & 744 & 661 \\
\hline \multirow{3}{*}{ Purchased property only } & 0.98 & 0.94 & $1.11^{\star}$ & $1.28^{\star \star}$ & $1.25^{\star \star}$ \\
\hline & $(1.50)$ & $(1.46)$ & $(1.34)$ & $(1.46)$ & $(1.57)$ \\
\hline & 607 & 607 & 607 & 599 & 558 \\
\hline \multirow{3}{*}{$\begin{array}{l}\text { Purchased property and retained target } \\
\text { management }\end{array}$} & $1.10^{*}$ & 1.24 & $1.44^{\star}$ & $1.71^{\star \star \star \star}$ & $1.72^{\star \star \star}$ \\
\hline & $(1.89)$ & $(2.35)$ & $(2.06)$ & $(2.18)$ & $(2.12)$ \\
\hline & 156 & 156 & 156 & 145 & 103 \\
\hline \multirow{3}{*}{ Private targets } & $1.04^{*}$ & 1.16 & $1.31^{\star}$ & $1.59^{\star \star \star}$ & $1.46^{\star \star}$ \\
\hline & (1.11) & $(1.42)$ & $(1.60)$ & $(2.02)$ & $(2.09)$ \\
\hline & 659 & 659 & 659 & 647 & 582 \\
\hline \multirow{3}{*}{ Public targets } & $0.87^{\star}$ & 1.03 & 1.12 & $1.31^{\star \star}$ & $1.26^{\star \star}$ \\
\hline & $(1.48)$ & $(0.99)$ & $(1.59)$ & $(1.49)$ & $(1.50)$ \\
\hline & 104 & 104 & 104 & 97 & 79 \\
\hline
\end{tabular}

The table reports the means, standard deviations (in parentheses), and the number of observations associated with Tobin's $Q$ for various types of acquisitions. Acquisitions include the entire sample, whether the acquirer retained the management of the target firm in addition to the assets of the target firm, the acquisition of only private firms, and acquisitions of only public firms. Here, ${ }^{\star \star \star},{ }^{\star *}$, and * indicate the differences of mean in a non-merger year relative to the mean statistics in the merger year at the 1,5 , and 10 percent significance levels, respectively. 
Table 10. Tobin’s Q by Acquisition Type and Financing Mechanism.

\begin{tabular}{|c|c|c|c|c|c|c|}
\hline \multirow{2}{*}{$\begin{array}{l}\text { Acquirers' Types and } \\
\text { Characteristics }\end{array}$} & \multicolumn{2}{|c|}{$\begin{array}{l}\text { Used "Primarily" Cash as a } \\
\text { Purchase Method }\end{array}$} & \multicolumn{2}{|c|}{$\begin{array}{l}\text { Used "Primarily" Stock as a } \\
\text { Purchase Method }\end{array}$} & \multicolumn{2}{|c|}{$\begin{array}{l}\text { Assuming Debt, Other Methods, } \\
\text { and/or Mixed Methods as a } \\
\text { Purchase Method }\end{array}$} \\
\hline & $\begin{array}{l}\text { One year after } \\
\text { merger }\end{array}$ & $\begin{array}{l}\text { Three years } \\
\text { after merger }\end{array}$ & $\begin{array}{l}\text { One year after } \\
\text { merger }\end{array}$ & $\begin{array}{l}\text { Three years } \\
\text { after merger }\end{array}$ & $\begin{array}{c}\text { One year after } \\
\text { merger }\end{array}$ & $\begin{array}{l}\text { Three years } \\
\text { after merger }\end{array}$ \\
\hline \multirow{3}{*}{ All sample } & 1.29 & 1.39 & 1.21 & 1.45 & 1.39 & $1.58^{\star \star}$ \\
\hline & $(1.60)$ & $(1.42)$ & $(1.69)$ & $(1.00)$ & $(1.29)$ & $(1.51)$ \\
\hline & 174 & 145 & 178 & 150 & 166 & 134 \\
\hline Purchased property only & 135 & 121 & 128 & 109 & 123 & 98 \\
\hline \multirow{3}{*}{$\begin{array}{l}\text { Purchased property and retained } \\
\text { target management }\end{array}$} & 1.71 & 1.78 & 1.14 & 1.29 & 1.23 & 1.66 \\
\hline & $(2.00)$ & $(2.09)$ & $(1.23)$ & $(1.34)$ & $(0.75)$ & $(0.75)$ \\
\hline & 39 & 24 & 50 & 41 & 43 & 36 \\
\hline Private targets & 1.59 & 1.89 & 1.52 & 1.79 & $1.20^{\star \star}$ & $1.37^{\star *}$ \\
\hline Public targets & 24 & 16 & 36 & 24 & 34 & 25 \\
\hline \multicolumn{7}{|c|}{$\begin{array}{l}\text { The table reports the means, standard deviations (in parentheses), and the number of observations associated with Tobin's } Q \text { for various types of } \\
\text { acquisitions according to the primary source of financing. Acquisitions include the entire sample, whether the acquirer retained the management of the } \\
\text { target firm in addition to the assets of the target firm, the acquisition of only private firms, and acquisitions of only public firms. We define the "primary" } \\
\text { source of financing as basing at least } 50 \% \text { of the payment method on that particular financing option. Accurate information on financing sources are } \\
\text { available for } 518 \text { mergers, therefore, the total number of observations reported according to financing sources below will not add up to the total number of } \\
\text { transactions reported in other tables. Here, }{ }^{\star \star \star},{ }^{\star *}, \text { and * indicate the differences of mean performance associated with mergers with stock (columns } 2 \\
\text { and } 3 \text { ) and debt and mixed purchase method (columns } 3 \text { and 4) relative to the primarily cash as a purchase method (columns } 1 \text { and } 2 \text { ) in the overall } \\
\text { sample as well as subsamples. }\end{array}$} \\
\hline
\end{tabular}


Table 11. Return on Assets by Acquisition Type.

\begin{tabular}{|c|c|c|c|c|c|}
\hline Acquirers' Types and Characteristics & $\begin{array}{c}\text { One Year Before } \\
\text { Merger }\end{array}$ & $\begin{array}{c}\text { Merger Year (Calendar } \\
\text { Year) }\end{array}$ & $\begin{array}{c}\text { One Year After } \\
\text { Merger }\end{array}$ & $\begin{array}{c}\text { Two Year After } \\
\text { Merger }\end{array}$ & $\begin{array}{c}\text { Three Year After } \\
\text { Merger }\end{array}$ \\
\hline \multirow{3}{*}{ All sample } & $4.02^{\star}$ & 4.33 & $4.95^{\star \star}$ & $5.05^{\star \star \star}$ & $5.31^{\star \star \star}$ \\
\hline & $(3.13)$ & $(4.87)$ & $(3.21)$ & $(3.12)$ & $(2.38)$ \\
\hline & 763 & 763 & 763 & 744 & 661 \\
\hline \multirow{3}{*}{ Purchased property only } & $3.63^{\star}$ & 3.98 & $4.76^{\star \star}$ & $4.80^{\star \star}$ & $5.01^{\text {** }}$ \\
\hline & $(5.00)$ & $(4.40)$ & $(3.68)$ & $(3.78)$ & $(3.17)$ \\
\hline & 607 & 607 & 607 & 599 & 558 \\
\hline \multirow{3}{*}{$\begin{array}{l}\text { Purchased property and retained target } \\
\text { management }\end{array}$} & $4.96^{\star}$ & 4.58 & $5.39^{\star \star}$ & $5.53^{\star \star \star}$ & $5.79^{\star \star \star}$ \\
\hline & $(4.03)$ & $(4.01)$ & $(2.89)$ & $(3.16)$ & $(3.69$ \\
\hline & 156 & 156 & 156 & 145 & 103 \\
\hline \multirow{3}{*}{ Private targets } & 4.35 & 4.49 & $5.11^{\star}$ & $5.22^{\star \star}$ & $5.42^{\star \star \star}$ \\
\hline & $(3.67)$ & $(4.00)$ & $(3.01)$ & $(3.60)$ & $(2.10)$ \\
\hline & 659 & 659 & 659 & 647 & 582 \\
\hline \multirow{3}{*}{ Public targets } & $2.97^{\star \star \star}$ & 4.02 & $4.88^{\star \star}$ & $4.95^{\star \star}$ & $5.34^{\star \star \star}$ \\
\hline & (3.19) & $(2.97)$ & $(2.90)$ & $(3.75)$ & $(2.38)$ \\
\hline & 104 & 104 & 104 & 97 & 79 \\
\hline
\end{tabular}

The table reports the means, standard deviations (in parentheses), and the number of observations associated with the return on assets for various types of acquisitions. Acquisitions include the entire sample, whether the acquirer retained the management of the target firm in addition to the assets of the target firm, the acquisition of only private firms, and acquisitions of only public firms. Here, ${ }^{\star \star \star},{ }^{\star \star}$, and ${ }^{\star}$ indicate the differences of mean in a non-merger year relative to the mean statistics in the merger year at the 1,5 , and 10 percent significance levels, respectively. 
Table 12. Return on Equity by Acquisition Type.

\begin{tabular}{|c|c|c|c|c|c|}
\hline Acquirers' Types and Characteristics & $\begin{array}{l}\text { One Year Before } \\
\text { Merger }\end{array}$ & $\begin{array}{c}\text { Merger Year (Calendar } \\
\text { Year) }\end{array}$ & $\begin{array}{l}\text { One Year After } \\
\text { Merger }\end{array}$ & $\begin{array}{c}\text { Two Years After } \\
\text { Merger }\end{array}$ & $\begin{array}{c}\text { Three Years After } \\
\text { Merger }\end{array}$ \\
\hline \multirow{3}{*}{ All sample } & $8.16^{\star \star}$ & 7.46 & $8.01^{\star}$ & $8.92^{\star \star \star}$ & 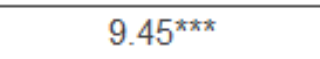 \\
\hline & $(6.28)$ & $(4.80)$ & $(3.60)$ & $(4.16)$ & $(8.64)$ \\
\hline & 763 & 763 & 763 & 744 & 661 \\
\hline \multirow{3}{*}{ Purchased property only } & $7.42^{\star}$ & 6.98 & 7.07 & $8.01^{\text {} \star * \star}$ & $9.02^{\star \star \star}$ \\
\hline & $(7.01)$ & $(7.45)$ & $(7.91)$ & $(4.06)$ & $(4.31)$ \\
\hline & 607 & 607 & 607 & 599 & 558 \\
\hline \multirow{3}{*}{$\begin{array}{l}\text { Purchased property and retained target } \\
\text { management }\end{array}$} & $10.77^{\star \star}$ & 9.43 & 10.51 & $10.63^{\star \star}$ & $10.16^{*}$ \\
\hline & $(6.89)$ & $(6.76)$ & $(6.93)$ & $(7.05)$ & $(6.83)$ \\
\hline & 156 & 156 & 156 & 145 & 103 \\
\hline \multirow{3}{*}{ Private targets } & $8.99^{*}$ & 8.47 & $9.14^{*}$ & $9.65^{\star \star}$ & $9.78^{\star \star}$ \\
\hline & $(6.83)$ & $(6.23)$ & (6.99) & $(4.49)$ & $(5.01)$ \\
\hline & 659 & 659 & 659 & 647 & 582 \\
\hline \multirow{3}{*}{ Public targets } & 8.02 & 8.09 & $7.43^{\star}$ & $8.77^{\star \star \star}$ & $8.97^{\star \star}$ \\
\hline & (7.11) & $(6.10)$ & (6.64) & $(4.02)$ & $(4.64)$ \\
\hline & 104 & 104 & 104 & 97 & 79 \\
\hline
\end{tabular}

The table reports the means, standard deviations (in parentheses), and the number of observations associated with the return on equity for various types of acquisitions. Acquisitions include the entire sample, whether the acquirer retained the management of the target firm in addition to the assets of the target firm, the acquisition of only private firms, and acquisitions of only public firms. Here, ${ }^{\star \star \star}$, ${ }^{\star \star}$, and ${ }^{*}$ indicate the differences of mean in a non-merger year relative to the mean statistics in the merger year at the 1,5 , and 10 percent significance levels, respectively. 
Table 13. Impact of Retaining Target Management on Tobin’s Q of the Acquiring Firm.

\begin{tabular}{|c|c|c|c|c|c|}
\hline Acquirers' Types and Characteristics & $\begin{array}{l}\text { One Year Before } \\
\text { Merger }\end{array}$ & $\begin{array}{c}\text { Merger Year (Calendar } \\
\text { Year) }\end{array}$ & $\begin{array}{l}\text { One Year After } \\
\text { Merger }\end{array}$ & $\begin{array}{l}\text { Two Years After } \\
\text { Merger }\end{array}$ & $\begin{array}{l}\text { Three Years After } \\
\text { Merger }\end{array}$ \\
\hline \multirow{2}{*}{ Intercept } & 0.0342 & 0.0825 & 0.2014 & 0.0136 & 0.0150 \\
\hline & $(0.84)$ & $(0.21)$ & $(0.69)$ & $(1.44)$ & $(1.47)$ \\
\hline \multirow{2}{*}{ Logarithm of assets } & 4.7924 & 3.2353 & 2.1821 & 1.7062 & 1.9421 \\
\hline & $(1.02)$ & $(1.19)$ & $(1.29)$ & $(1.53)$ & $(1.16)$ \\
\hline \multirow{2}{*}{ Sales-to-assets ratio } & $2.1461^{\star}$ & $1.7320^{\star}$ & $0.8553^{\star}$ & 1.0124 & $1.0423^{\star}$ \\
\hline & $(1.77)$ & $(1.66)$ & $(1.71)$ & $(1.59)$ & $(1.72)$ \\
\hline \multirow{2}{*}{ Debt to equity ratio } & -0.1993 & -0.0971 & -0.1255 & -0.0754 & 0.1671 \\
\hline & $(1.59)$ & $(1.49)$ & $(1.64)$ & $(1.39)$ & $(1.61)$ \\
\hline \multirow{2}{*}{$\begin{array}{l}\text { Retained target management dummy } \\
\text { (RMD) }\end{array}$} & $0.4015^{\star \star}$ & $0.3496^{\star \star}$ & $0.2833^{\star \star}$ & $0.2182^{\star \star}$ & $0.2274^{\star \star}$ \\
\hline & $(1.96)$ & $(2.10)$ & $(2.72)$ & $(2.51)$ & $(2.20)$ \\
\hline Adjusted $R^{2}$ & 0.1679 & 0.1685 & 0.1779 & 0.1570 & 0.1474 \\
\hline F-Statistics & $7.54^{\star \star \star}$ & 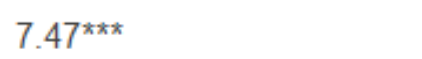 & $7.39^{\star \star \star}$ & $6.52^{\star \star \star}$ & $6.29^{\star \star \star}$ \\
\hline Number of observation & 763 & 763 & 763 & 744 & 661 \\
\hline
\end{tabular}

The table reports the results of ordinary least squares regressions of the log of assets, sales-to-assets ratio, debt to equity ratio, and a dummy variable of whether target management was retained (one if target management is retained, zero otherwise) on Tobin's $Q$. Here, ${ }^{\star \star *},{ }^{* *}$, and * indicate that parameters are significantly different from zero at the 1, 5 , and 10 percent significance levels, respectively, using a two-tailed test. The $t$-statistics in the parenthesis are adjusted for "White-corrected" standard errors. Estimations below also include year dummies, which are not reported for brevity. 


\section{References}

Agrawal, A., Jaffe, J. F., \& Mandelker, G. N. (1996). The post-merger performance of acquiring firms: A re-examination of an anomaly. Journal of Finance, 47, 1605-1621.

Aktas, N., de Bodt, E., \& Roll, R. (2013). Learning from repetitive acquisitions: Evidence from the time between deals. Journal of Financial Economics, 108, 99-117.

Allen, P., \& Sirmans, C. F. (1987). An analysis of gains to acquiring firm’s shareholders: The special case of REITs. Journal of Financial Economics, 18, 175-184.

Ambrose, B., Ehrlich, S. R., Hughes, W. T., \& Wachter, S. M. (2000). REIT economies of scale: Fact or fiction? Journal of Real Estate Finance and Economics, 20(2), 211-224.

Asquith, P. (1983). Merger bids, uncertainty and stockholder returns. Journal of Financial Economics, 11, 51-84.

Barber, B., \& Lyon, J. (1997). Detecting long-run abnormal stock returns: The empirical power and specifications of test statistics. Journal of Financial Economics, 43, 341-372.

Brav, A. (2000). Inference in long-horizon event studies: A parametric bootstrap approach with applications to initial public offerings. Journal of Finance, 55, 1979—2016.

Brown, S., \& Warner, J. B. (1985). Using daily stock returns: The case of event studies. Journal of Financial Economics, 14, 3-32.

Burns, N., Francis, B., \& Hasan, I. (2007). Cross-listing and legal bonding: Evidence from mergers and acquisitions. Journal of Banking and Finance, 31, $1003-1031$.

Campbell, R., Ghosh, C., \& Sirmans, C. F. (2001). The information content of method of payment in mergers: Evidence from real estate investment trusts. Real Estate Economics, 29, 361-387. 
Chang, S. (1998). Takeovers of privately held targets, methods of payment, and bidder returns. Journal of Finance, 53(2), 773-784.

Chi, T. (1994). Trading in strategic resources: Necessary conditions, transaction cost problems, and choice of exchange structure. Strategic Management Journal, 15(4), 271-290.

Choi, S., Francis, B., \& Hasan, I. (2010). Cross border M\&As and bank risk: Evidence from the bond market. Journal of Money, Credit, and Banking, 42, 615-645.

Coff, R. W. (1999). How buyers cope with uncertainty when acquiring firms in knowledge intensive industries: Caveat emptor. Organization Science, 10(2), 144-161.

Coff, R. W. (2002). Human capital, shared expertise and the likelihood of impasse in corporate acquisitions. Journal of Management, 28(1), 107-128.

Comment, R., \& Schwert, G. W. (1996). Poison or placebo? Evidence on the deterrent and wealth effects of modern antitakeover measures. Journal of Financial Economics, 39, 343.

Corgel, J. B., McIntosh, W., \& Ott, S. H. (1995). Real estate investment trusts: A review of the financial economics literature. Journal of Real Estate Literature, 3, 13-43.

Daines, R. (2001). Does Delaware law improve firm value? Journal of Financial Economics, 62, $525-558$.

Dodd, P. (1980). Merger proposals, manager discretion and stockholder wealth. Journal of Financial Economic, 8, 105-138.

Eckbo, B. E. (1983). Horizontal mergers, collusion and stockholder wealth. Journal of Financial Economics, 11, 241-274.

Elayan, F., \& Young, P. (1994). The value of control: Evidence from full and partial acquisitions in the real estate industry. Journal of Real Estate Finance and Economics, 8(2), 167-182. 
Faccio, M., McConnell, J. J., \& Stolin, D. (2006). Returns to acquirers of listed and unlisted targets. Journal of Financial Quantitative Analysis, 41, 197-220.

Fee, C. E., \& Thomas, S. (2004). Sources of gains in horizontal mergers: Evidence from customer, supplier, and rival firms. Journal of Financial Economics, 74, 423-460.

Francis, B., Hasan, I., \& Sun, X. (2008). Financial market integration and the value of global diversification: Evidence for U.S. acquirers in cross-border mergers and acquisitions. Journal ofBanking and Finance, 32, 1522-1640.

Francis, B., Hasan, I., Sun, X., \& Waisman, M. (2014). Can firms learn by observing? Evidence from cross-border M\&As. Journal of Corporate Finance, 25, 202-215.

Franks, J., Harris, R., \& Titman, S. (1991). The post-merger share-price performance of acquiring firms. Journal of Financial Economics, 17, 81-96.

Fuller, K., Netter, J., \& Stegemoller, M. (2002). What do returns to acquiring firms tell us? Evidence from firms that make many acquisitions. Journal of Finance, 57(4), 1763-1793.

Giammarino, R. M., \& Heinkel, R. L. (1986). A model of dynamic takeover behavior. Journal of Finance, 41(2), 465-480.

Glascock, J., Davidson, W., III., \& Sirmans, C. F. (1991). The gains from corporate selloffs: The case of real estate assets. American Real Estate and Urban Economics Association Journal, 19(4), 567-582.

Gosh, A. (2001). Does operating performance really improve following acquisition? Journal of Corporate Finance, 7, 151-178.

Grinblatt, M., \& Titman, S. (2002). Financial markets and corporate strategy (2nd ed.). New York, NY: McGraw Hill. 
Hansen, R. G., \& Lott, J. R., Jr. (1996). Externalities and corporate objectives in a world with diversified shareholder/consumers. Journal of Financial Quantitative Analysis, 31, 43-68.

Hardin, W. G., III., \& Wolverton, M. L. (1999). Equity REIT property acquisitions: Do apartment REITs pay a premium. Journal of Real Estate Research, 17, 113-126.

Hartzell, J., Kallberg, J. G., \& Liu, C. H. (2003, July). The role of corporate governance in initial public offerings: Evidence from real estate investment trusts. Stern School of Business Working Paper.

Hasan, I., Kallberg, J. G., \& Liu, C. H. (2002, December). REIT mergers and economies of scale. Stern School of Business Working Paper.

Healy, P. M., Palepu, K. G., \& Ruback, R. (1992). Does corporate performance improve after mergers? Journal of Financial Economics, 31, 135-173.

Healy, P. M., Palepu, K. G., \& Ruback, R. (1997). Which takeovers are profitable? "Strategic versus financial?”. Sloan Management Review, 38, 45-57.

Hietala, P., Kaplan, S., \& Robinson, D. (2002). What is the price of hubris? Using takeover battles to infer overpayments and synergies. NBER Working Paper, INSEAD.

Hubbard, R. G., \& Palia, D. (1999). A reexamination of the conglomerate merger wave in the 1960s: An internal capital markets view. Journal of Finance, 54(3), 1131-1152.

Kallberg, J. G., Liu, C. H., \& Trzcinka, C. (2000). The value added from investment managers: An examination of funds of REITs. Journal of Financial and Quantitative Analysis, 35(3), 387-408.

Kohers, N., \& Ang, J. (2000). Earnouts in mergers: Agreeing to disagree and agreeing to stay. Journal of Business, 73, 445 -476. 
Krainer, R. E. (2012). Financial system instability: Threats, prevention, management and resolution. Journal of Financial Stability, 8, 121-133.

Loughran, T., \& Vijh, A. M. (1997). Do long-term shareholders benefit from corporate acquisitions? Journal of Finance, 52, 1765-1790.

Malatesta, P. (1983). The wealth effect of merger activity and the objective function of merging firms. Journal of Financial Economics, 11, 155-182.

Martin, K., \& McConnell, J. (1991). Corporate performance, corporate takeovers, and management turnover. Journal of Finance, 46, 671-687.

Matsusaka, J. (1993). Takeover motives during the conglomerate merger wave. RAND Journal of Economics, 24(3), 357-379.

McIntosh, W., Ott, S. H., \& Liang, Y. (1995). The wealth effects of real estate transactions: The case of REITs. Journal of Real Estate Finance and Economics, 10(3), 299-306.

Mitchell, M. L., \& Mulherin, J. H. (1996). The impact of industry shocks on takeover and restructuring activity. Journal of Financial Economics, 73, 201-208.

Moeller, S., Schlingemann, F., \& Stulz, R. (2004). Firm size and the gains from acquisitions. Journal of Financial Economics, 17, 81-96.

Morck, R., Shleifer, A., \& Vishny, R. W. (1988). Characteristics of targets of hostile and friendly takeovers. In A. Auerbach (Ed.), Corporate takeovers: Causes and consequences. Chicago, IL: University of Chicago Press.

Morck, R., Shleifer, A., \& Vishny, R. W. (1989). Alternative mechanisms for corporate control. American Economic Review, 89, 842-852.

Officer, M. S. (2007). The price of corporate liquidity: Acquisition discounts for unlisted targets. Journal of Financial Economics, 83, 571—598. 
Officer, M. S., Poulsen, A. B. \& Stegemoller, M. (2009). Target-firm information asymmetry and acquirer returns. Review of Finance, 13, 467-493.

Ongena, S., \& Penas, M. F. (2009). Bondholders' wealth effects in domestic and cross-border bank mergers. Journal of Financial Stability, 5, 256-271.

Osano, H. (2004). Stock options and employees’ firm-specific human capital under the threat of divestitures and acquisitions. Journal of Corporate Finance, 10, 615—638.

Porter, M. S. (1997). REITs due for upsurge in M\&A market. Investment Dealer’s Digest, Mergers \& Acquisitions Report, 10(40), October 6, p. 1.

Ratcliffe, C., \& Dimovski, W. (2012). REIT mergers and acquisitions: A meta-analysis. Journal of Property Investment and Finance, 30, 241-256.

Roll, R. (1986). The hubris hypothesis of corporate takeovers. Journal of Business, 59, 197_216.

Rosen, R. (2005). Merger momentum and investor sentiment: The stock market reaction to merger announcements. Journal of Business.

Ross, S., Westerfield, R., \& Jaffe, J. (2002). Corporate finance (6th ed.). McGraw-Hill.

Schalop, L. (1998a). Real Estate M\&A, Part I. JP Morgan Securities, May 26.

Schalop, L. (1998b). Real Estate M\&A, Part II. JP Morgan Securities, May 27.

Schlingemann, F. (2004). Financing decisions and bidder gains. Journal of Corporate Finance, $10,683-701$.

Schnitzer, M. (1996). Hostile versus friendly takeovers. Economica, 63, 37—55.

Scholes, M., \& Williams, J. (1977). Estimating betas from nonsynchronous data. Journal of Financial Economics, 5, 309-337. 
Schwert, G. W. (1996). Markup pricing in mergers and acquisitions. Journal of Financial Economics, 41, 153-192.

Schwert, G. W. (2000). Hostility in takeovers: In the eyes of the beholder? Journal of Finance, 55(6), 2599-2640. 